\title{
Accumulation of silicon and arrangement and shapes of silica bodies in corn leaves
}

\author{
F.A. Andrade ${ }^{1}$, O. Andrade Júnior ${ }^{2}$, C.G.T.J. Andrade ${ }^{3}$ and E. Miglioranza ${ }^{1}$ \\ ${ }^{1}$ Departamento de Agronomia, Universidade Estadual de Londrina, \\ Londrina, PR, Brasil \\ ${ }^{2}$ Departamento de Agronomia, Universidade do Oeste Paulista, \\ Presidente Prudente, SP, Brasil \\ ${ }^{3}$ Departamento de Biologia, Universidade Estadual de Londrina, \\ Londrina, PR, Brasil \\ Corresponding author: F.A. Andrade \\ E-mail: felipearanhaa@hotmail.com
}

Genet. Mol. Res. 13 (1): 1690-1696 (2014)

Received March 20, 2013

Accepted September 12, 2013

Published January 24, 2014

DOI http://dx.doi.org/10.4238/2014.January.24.6

\begin{abstract}
Different plant species have different levels and locations of silicon accumulation in their tissues, and may or may not have silica bodies. Grasses usually accumulate these bodies, which may have different shapes depending on the genotype. Besides, this element can be beneficial to crops. The present study aimed to examine the forms and locations of silicon accumulation, as well as silicon content, in flag leaves of corn (Zea mays L.). This was a field experiment with two cultivars of corn: Coodetec 384 and Pioneer BG7065H. Four months after sowing, the flag leaves of the corn cultivars were obtained for determination of the silicon content of leaf tissue with the use of plasma atomic emission spectrometry, as well as examination of the different forms and locations of silicon accumulation using scanning electron microscopy and energy dispersive X-ray spectroscopy. The two cultivars were found to accumulate foliar silicon, primarily at the base of the trichomes and on the venation. Also, silica bodies in the shape of four-leaf clovers and dumbbells were detected, and the cultivar
\end{abstract}


Coodetec 384 showed a silicon content in leaf tissue $26 \%$ higher than that of Pioneer BG7065H.

Key words: Zea mays L.; Silica bodies; Scanning electron microscopy; Energy dispersive X-ray spectroscopy

\section{INTRODUCTION}

Silicon $(\mathrm{Si})$ is considered a particularly useful element that can provide many benefits to several vegetable crops (Rodrigues et al., 2011). In corn plants, for example, the increase in the content of this element makes them more resistant to attack by Spodoptera frugiperda (J.E. Smith) (Lepidoptera: Noctuidae), and by the aphid Rhopalosiphum maidis (Fitch) (Hemiptera: Aphididae) (Goussain et al., 2002; Moraes et al., 2005), besides reducing transpiration rate (Gao et al., 2006), resulting in better use of water.

Soil solution has a silica content that varies between 28 and $32 \%$ of all the material present in the solution (Malavolta, 2006). Plants can absorb it in hydrated form $\left(\mathrm{SiO}_{2} \cdot \mathrm{nH}_{2} \mathrm{O}\right)$, which is deposited in their tissues, and silica bodies of different shapes and sizes may occur depending on the plant species.

The silica bodies accumulate mainly in the family Poaceae (corn), in organs such as leaves, seeds, fruits, roots and stems, where they may be deposited inside the cells or in their walls (Runge, 1999; Alvarez et al., 2005). Silica bodies are microscopic and are precipitated in the tissues of plants during their life cycle. In grasses, they create support structures (Piperno and Pearsall, 1998; Medeanic et al., 2008).

These silica bodies provide different contributions, where they are important tools in paleoenvironmental reconstructions, supporting palynological evidence of past vegetation distribution. Moreover, they are of paramount importance in paleoenvironmental reconstructions because they are better preserved in the sediments than pollen and spores (Medeanic et al., 2008).

Plants, including genotypes of the same species, can absorb $\mathrm{Si}$, with this accumulation being visualized by microscopy, in different ways in their tissues, with or without formation of silica bodies (Andrade et al., 2012a,b). Sávio et al. (2011) observed that Brachiaria decumbens cv. Basilisk and Panicum maximum cv. Mombaça differ in Si content in the aerial part of the plant, with B decumbens reported to having higher Si content than P maximum. These differences were also observed between the different genotypes in sugar cane (Saccharum spp L.) (Korndörfer et al., 2000).

Given that plants with higher Si content and with formation of silica bodies may be favored by the beneficial effects of such element, and that the different corn genotypes can accumulate Si differently, and have different levels, the present study aimed to assess the forms and locations of accumulated silicon and content of silicon in flag leaves of two corn cultivars grown under the same conditions.

\section{MATERIAL AND METHODS}

The samples of flag leaves (leaves below the ear of corn) for assessment of silicon content and silica forms and locations of accumulation were collected in an experiment in the city of Apucarana, Paraná. This city has an altitude of $746 \mathrm{~m}$ and coordinates $23^{\circ} 50^{\prime} \mathrm{S}$ and 
$51^{\circ} 53^{\prime} \mathrm{W}$. The experimental area has a typic hapludox (oxisol) soil, moderately acidic, clayey (Embrapa, 2006). The results of chemical analysis of the soil are as follows: $\mathrm{pH}\left(\mathrm{CaCl}_{2}\right)=5.5$; $\mathrm{H}+\mathrm{Al}=17 \mathrm{mmolc} / \mathrm{dm}^{3} ; \mathrm{Ca}^{2+}=15 \mathrm{mmolc} / \mathrm{dm}^{3} ; \mathrm{Mg}^{2+}=5 \mathrm{mmolc} / \mathrm{dm}^{3} ; \mathrm{Al}^{3+}=0.0 \mathrm{mmolc} / \mathrm{dm}^{3} ;$ $\mathrm{K}^{+}=0.9 \mathrm{mmolc} / \mathrm{dm}^{3} ; \mathrm{P}=48 \mathrm{mg} / \mathrm{dm}^{3} ; \mathrm{S}=6.5 \mathrm{mg} / \mathrm{dm}^{3} ;$ sum of bases $=30 \mathrm{mmolc} / \mathrm{dm}^{3} ; \mathrm{CTC}=$ $45.5 \mathrm{mmolc} / \mathrm{dm}^{3} ; \mathrm{V} \%=50 ; \mathrm{M} . \mathrm{O}=8 \mathrm{~g} / \mathrm{dm}^{3}$.

According to Köppen's classification, the climate of Apucarana - PR is subtropical $\left(\mathrm{Cfa}\right.$,), with an average temperature of less than $18^{\circ} \mathrm{C}$ in the coldest month of the year and higher than $22^{\circ} \mathrm{C}$ in the warmest month of the year, with hot summers and infrequent frosts, and the highest amounts of rain occurring in summer months (Instituto Agronômico do Paraná, 2012).

Corn was sown in the growing year of 2012, in March. Two corn genotypes were sown: Coodetec 384 and Pioneer BG7065H, using a 0.90-m spacing between rows, with six plants per linear meter. The total area of the experiment was $6000 \mathrm{~m}^{2}, 3000 \mathrm{~m}^{2}$ used for each cultivar.

Fertilization consisted in applying $248 \mathrm{~kg} / \mathrm{ha}$ of the formulation 04-30-10 (N-P-K), 20 days after seedling emergence (DAE). Atrazine Nortox $500 \mathrm{SC}^{\circledR}$ was applied at a dose of 2.9 $\mathrm{L} /$ ha for the control of grassy weeds, and Callisto ${ }^{\circledR}$, at a dose of $0.62 \mathrm{~L} / \mathrm{ha}$, for the control of grassy weeds and dicotyledons. Fertilization was performed at $25 \mathrm{DAE}$ with the use of super $\mathrm{N}$, at a dose of $165 \mathrm{~kg} / \mathrm{ha}$.

Scanning electron microscopy (SEM) images were prepared for analysis of the forms and locations of accumulated silicon, using one flag leaf randomly collected from each plant of the two corn cultivars four months after sowing, with six replications. Thus, six flag leaves were obtained from each cultivar to perform the analyses.

After collection, the leaves were cut in their central parts, so that a fragment of around $4 \mathrm{~mm}^{2}$ was obtained for each leaf, generating six fragments in total for assessment of each cultivar. Afterwards, the fragments were immersed in a fixative solution containing 5\% formaldehyde, $90 \%$ ethanol and 5\% acetic acid (FAA) for $24 \mathrm{~h}$ at room temperature. The fragments were dehydrated with an increasing series of ethanol (70, 80,90 and $100 \%$ ) and critical point dried in $\mathrm{CO}_{2}$ (Bal Tec CPD 030). The samples were then glued on "stubs" with the adaxial and abaxial surfaces facing up and covered with carbon using Sputter coater Bal-Tec SCD 050. For the visualization of the forms and locations of accumulated silicon, the samples were analyzed by energy dispersive X-ray spectroscopy (EDS-Oxford), the INCA software, coupled to a scanning electronic microscope - FEI Quanta 200. Regarding the assessment of leaf silicon content, the flag leaves were collected in the same way as for SEM analysis, but with three replicates, and the whole leaves were used, without the removal of fragments. The leaves were dried at $65^{\circ} \mathrm{C}$, and once they reached constant weight, they were ground using a "Willey type" mill for determination of silicon content. For this determination, the samples were digested with nitrohydrochloric acid, and $24 \mathrm{~h}$ later the samples were analyzed by plasma atomic emission spectrometry (Perkin Elmer Optima 5200 DV).

\section{RESULTS AND DISCUSSION}

Sem showed accumulation of silicon in the form of silica bodies and in leaf tissues on both surfaces of the leaves analyzed. Accumulation of silicon in the tissues occurred mainly at the base of trichomes and on the venation (Figure 1). 


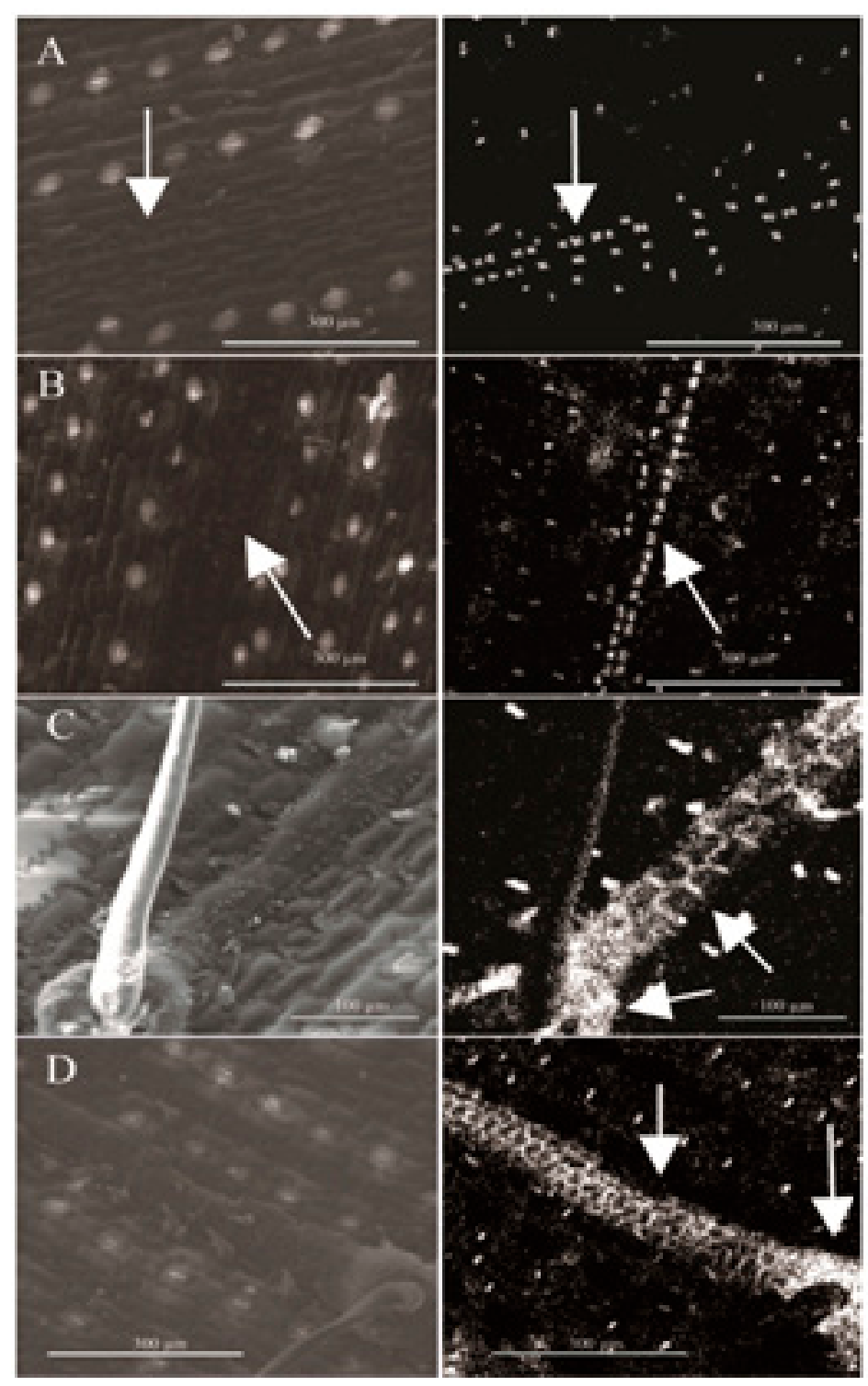

Figure 1. Scanning electron micrographs illustrating the mapping of silicon ( $\mathrm{Si}$ ) in leaf tissue and in the form of silica bodies (right) in the leaf epidermis of corn (left). A. Si in the abaxial epidermis of the Coodetec 384 cultivar. B. $\mathrm{Si}$ in the adaxial epidermis of Pioneer BG7065H cultivar. C. D. Si at the base of trichomes and on the venation of Pioneer BG7065H and Coodetec 384 cultivars, respectively.

Besides, the silica bodies were randomly arranged on the leaf surfaces or concentrated in rows, in the shape of four-leaf clovers and dumbbells. No differences were found in the two corn cultivars regarding the form of silicon accumulated in the leaf tissues and the arrangement and shape of silica bodies (Figure 2). 


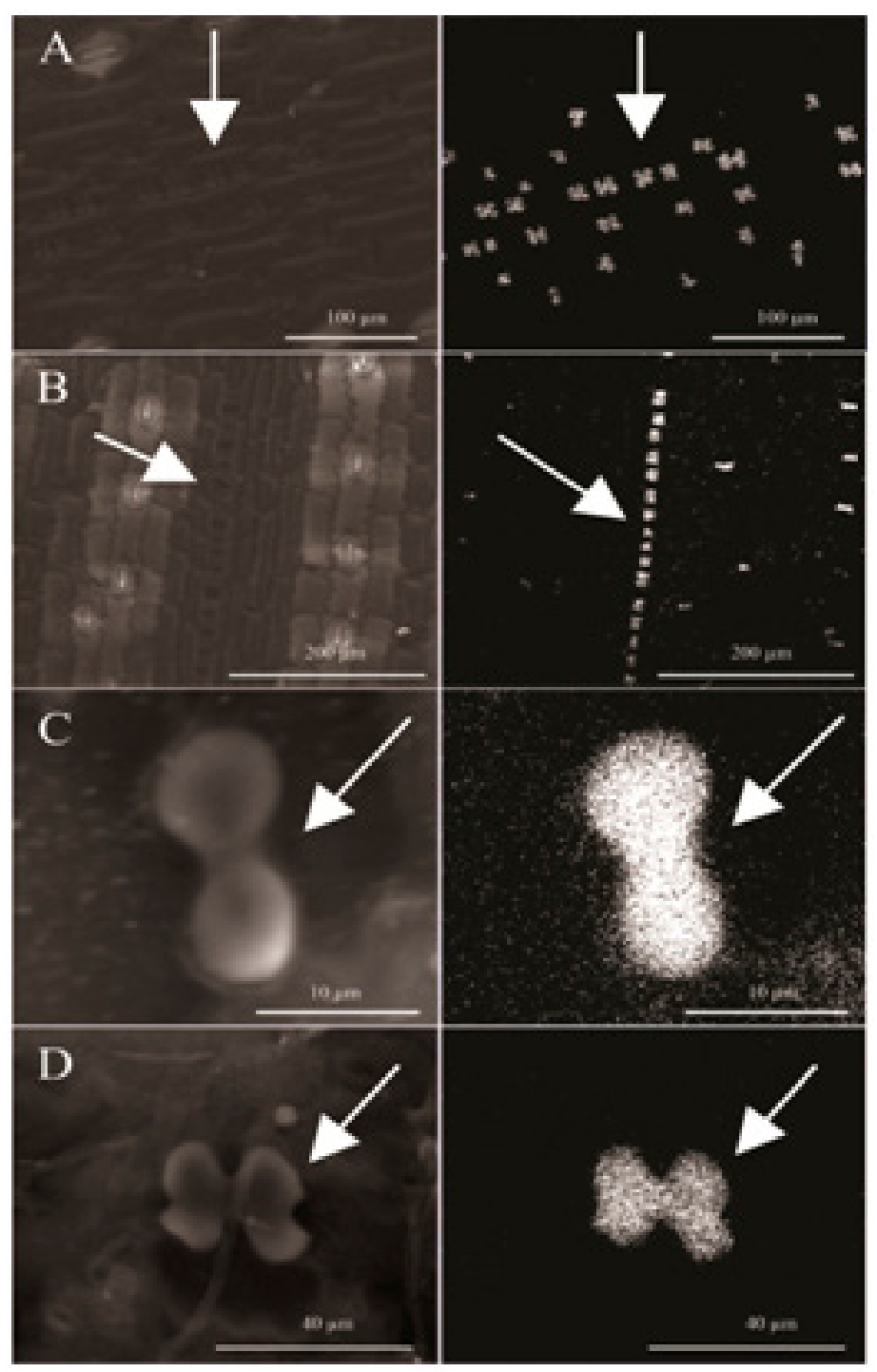

Figure 2. Scanning electron micrographs illustrating the mapping of silicon in leaf tissue and in the form of silica bodies (right) in the leaf epidermis of corn (left). A. Accumulated silica bodies scattered in the abaxial surface of Coodetec 384 cultivar. B. Silica bodies accumulated in rows on the abaxial surface of the Pioneer BG7065H cultivar C. Silica body in the form of dumbbells. D. Silica body in the form of a four-leaf clover.

Regarding the leaf content of silicon, the Coodetec 384 cultivar showed $726.38 \mathrm{mg} / \mathrm{kg}$ silicon, while Pioneer BG7065H was found to contain $531.40 \mathrm{mg} / \mathrm{kg}$.

Grasses accumulate a lot of silicon, at concentrations greater than 1\% (Ma et al., 2001). In fact, silicon is the second most abundant chemical element in the earth's crust and soil (Epstein and Bloom, 2005). These factors may explain leaf accumulation of silicon by the plants used in the present study, even though they were not fertilized with silicon acid. Be- 
sides, corn belongs to the family Poaceae, which, along with Cyperaceae, accumulates silicon (Hodson et al., 2005).

Andrade et al. (2012a), in their study of the accumulation of silica bodies in different wheat genotypes (Triticum aestivum L.), cultivated in oxisol, A-horizon and very clayey texture, found differences in the arrangement of these bodies on the adaxial epidermis of flag leaves of the different genotypes. Such differences were not observed in the present study where the two corn cultivars showed the same arrangements of silica bodies on both leaf surfaces. This may have occurred due to the genetic characteristics of the studied species. Thus, further experiments with a larger number of genotypes are needed.

No differences were observed regarding the shapes of the silica bodies (four-leaf clover and dumbbell) between the two cultivars used in the experiment probably because the plants were grown in the same type of soil, under the same climatic conditions. Generally, silica bodies may have more varied forms and quantities, both in plants and in the soil (Costa et al., 2010a,b). These differences can be seen when the species have different genetic characteristics and are grown in different types of soil or under different climate conditions.

Crops in hot and humid environments, which may favor plant evapotranspiration, may cause precipitation of monosilicic acid in gel form, and not in the form of silica bodies. On the other hand, in dry environments, absorption of monosilicic acid would not be so substantial due to the low amount of silica available for plant uptake (Ramírez-Sandrez et al., 2007).

Nevertheless, when the variable analyzed was leaf content of silicon it was found that the Coodetec 384 cultivar accumulated around 26\% more silicon than the Pioneer BG7065H cultivar. Again, the genetic traits of each genotype may explain these findings, for the plants grown under the same conditions.

Silicon content can be influenced by the growing conditions of a given crop. Factors such as increased temperature, for example, can enhance plant transpiration, increasing their silicon content (Su et al., 2002). According to Duda et al. (2001), in their study of wheat, plant growth and transpiration and the availability of silicon in the soil usually determine the absorption and accumulation of Si for this crop.

The characterization of silica bodies in corn crops is of utmost importance, for these bodies may have a single form for a given species. Also, these bodies can be used in studies for reconstitution of paleovegetations and paleoclimates (Runge, 1999).

Because silicon favors the performance of various crops, and in the present study it was found that different corn cultivars have different silicon levels in leaves, under the same growing conditions, these data may assist in corn crop management decisions, e.g., in those cases where plants with higher concentrations of silicon are needed to minimize the effect of possible stresses such as pests and diseases, as well as water stress.

\section{ACKNOWLEDGMENTS}

Research supported by CAPES, in form of scholarship granted to the first author. Thanks go to Laborsolo for reading the silicon samples.

\section{REFERENCES}

Alvarez JM, Rocha JF and Machado SR (2005). Estrutura foliar de Loudetiopsis chrysothrix (Nees) Conert e Tristachya leiostachya Nees (Poaceae). Rev. Bras. Bot. 28: 23-37.

Genetics and Molecular Research 13 (1): 1690-1696 (2014)

CFUNPEC-RP www.funpecrp.com.br 
Andrade FA, Andrade CGTJ and Miglioranza E (2012a). Detecção de sílica em folha bandeira de trigo. Semin. Ciênc. Agrár. 33: 2555-2562.

Andrade FA, Andrade CGTJ, Fukuji AYS and Miglioranza E (2012b). Silicon accumulation in Phaseolus vulgaris L. leaves observed by scanning electron microscopy. Annu. Rep. Bean Improv. Coop. 55: 243-244.

Costa LM, Moreau AMSS and Moreau MS (2010a). Estabilidade da sílica biogênica extraída de capim Jaraguá (Hyparrhenia rufa) em solução de NaOH. Quim. Nova 33: 1658-1663.

Costa LM, Santos RF, Schaefer CEGR, Moreau MSS, et al. (2010b). Ocorrência de corpos silicosos em horizontes superficiais de solos de diferentes ecossistemas. Rev. Bras. Ciênc. Solo 34: 871-879.

Duda R, Gutser R and Schmidhalter U (2001). Characterizing Site Specific Differences in Water Availability. In:. Plant Nutrition: Food Security and Sustainability of Agro-Ecosystems Through Basic and Applied Research. Fourteenth International Plant Nutrition Colloquium, Hannover, 390-391.

Embrapa (2006). Sistema Brasileiro de Classificação de Solos. Centro Nacional de Pesquisa de Solos. 2nd edn. Embrapa Solos, Rio de Janeiro, 306.

Epstein E and Bloom AJ (2005). Mineral Nutrition of Plants: Principles and Perspectives. 2nd edn. Sinauer Associates, Sunderland.

Gao X, Zou C, Wang L and Zhang F (2006). Silicon decreases transpiration rate and conductance from stomata of maize plants. J. Plant Nutr. 29: 1637-1647.

Goussain MM, Moraes JC, Carvalho JG, Nogueira NL, et al. (2002). Efeito da aplicação de silício em plantas de milho no desenvolvimento biológico da lagarta-do-cartucho Spodoptera frugiperda (J.E.Smith) (Lepidoptera: Noctuidae). Neotrop. Entomol. 31: 305-310.

Hodson MJ, White PJ, Mead A and Broadley MR (2005). Phylogenetic variation in the silicon composition of plants. Ann. Bot. 96: 1027-1046.

Instituto Agronômico do Paraná - IAPAR (2012). Cartas climáticas do Estado do Paraná. Available at: [http://www.iapar. br/modules/conteudo/conteudo.php?conteudo=615]. Accessed August 20, 2012.

Korndörfer GH, Benedini M, Paula FB and Chagas RCS (2000). Cimento como fonte de silício para a cana-de-açúcar. Stab 19: 30-33.

Ma JF, Miyake Y and Takahashi E (2001). Silicon as a Beneficial Element for Crop Plants. In: Silicon in Agriculture (Datnoff LE, Snyder G and Korndörfer GH, eds.). Elsevier Science, New York, 17-39.

Malavolta E (2006). Manual de Nutrição Mineral de Plantas. 2nd edn. Agronômica Ceres, São Paulo.

Medeanic S, Cordazzo CV, Corrêa ICS and Mirlean N (2008). Os fitólitos em gramíneas de dunas do extremo sul do Brasil: variabilidade morfológica e importância nas reconstruções paleoambientais costeiras. Gravel 6: 1-14.

Moraes JC, Goussain MM, Carvalho GA and Costa RR (2005). Feeding non-preference of the corn leaf aphid Rhopalosiphum maidis (Fitch, 1856) (Hemiptera: Aphididae) to corn plants (Zea mays L.) treated with silicon. Ciênc. Agrotechnol. 29: 761-766.

Piperno DR and Pearsall DM (1998). The Silica Bodies of Tropical American Grasses: Morphology, Taxonomy, and Implications for Grass Systematics and Fossil Phytolith Identification. Smithsonian Contributions to Botany. Smithsonian Institution Press, Washington.

Ramírez-Sanchez HU, Zárate-del-valle PF, García Guadalupe ME, De la Torre Villasenõr O, et al. (2007). Disolución de sílice biogênica em sedimentos de lagos utilizados como bioindicadores de calidad del agua. e-Gnosis 5: 1-19.

Rodrigues FA, Oliveira LA, Korndörfer AP and Korndörfer GH (2011). Silício: Um elemento benéfico e importante para as plantas. Informações Agronôm. 134: 14-20.

Runge F (1999). The opal phytolith inventory of soils in Central Africa - Quantities, shapes, classification, and spectra. Rev. Palaeobot. Palynol. 107: 23-53.

Sávio FL, Silva GC, Teixeira IR and Borém A (2011). Produção de biomassa e conteúdo de silício em gramíneas forrageiras sob diferentes fontes de silicato. Semina. Ciênc. Agrár. 32: 103-110.

Su RZ, Liu ZM, Li J and Ai J (2002). Study on silica distribution of wheat straw surface. Sci. Silvae Sin. 38: 99-102. 